\title{
Simple Visual Assay for Determination of Pasteurella haemolytica Cytotoxin Neutralizing Antibody Titers in Cattle Sera $\dagger$
}

\author{
MARTHA J. GENTRY, ${ }^{1 *}$ ANTHONY W. CONFER, ${ }^{2}$ AND JUDY A. KREPS ${ }^{2}$ \\ Departments of Veterinary Parasitology, Microbiology, Public Health, ${ }^{1}$ and Veterinary Pathology, ${ }^{2}$ Oklahoma State \\ University, Stillwater, Oklahoma 74078
}

Received 10 June 1985/Accepted 5 September 1985

\begin{abstract}
A simple visual assay is described for determining the capacity of bovine serum to neutralize the cytotoxin produced by Pasteurella haemolytica serotype 1 . The test was reproducible from day to day with different target cell populations and cytotoxin preparations. Cytotoxin neutralization titers obtained by the visual assay were comparable to those determined by the trypan blue exclusion and ${ }^{51} \mathrm{Cr}$-release methods. The visual assay was used to measure neutralization titers of bovine sera obtained from vaccination experiments and fractions of purified serum obtained by gel filtration. The major advantages of the visual assay over other assays are that it is rapid, inexpensive, and does not use radioisotopes. It also does not require specialized equipment, making it adaptable to most laboratories.
\end{abstract}

Pasteurella haemolytica serotype 1, the bacterium most commonly associated with the severe fibrinous pneumonia of shipping fever (pneumonic pasteurellosis) in cattle, produces a cytotoxin which is toxic for bovine pulmonary alveolar macrophages $(3,13)$ and peripheral blood leukocytes $(4,11)$. Cytotoxic effects of the organism on phagocytes may contribute to the severity of lung lesions seen in shipping fever $(11,12)$; thus, cytotoxin may play an important role in the pathogenesis of the disease (18).

$P$. haemolytica cytotoxin is immunogenic, and it has been proposed as a potential immunizing agent for cattle (10). Neither fetal bovine serum nor serum from colostrumdeprived newborn calves neutralizes the effects of cytotoxin on bovine peripheral blood leukocytes $(2,6,9)$. However, cytotoxin-neutralizing $(\mathrm{CN})$ antibodies have been demonstrated in sera from immunized rabbits (19), adult bovine sera $(2,6,20)$, bovine nasal secretions and lung washings (6), and bronchoalveolar washings from experimentally vaccinated calves (J. Opudo-Asibo, E. L. Townsend, S. K. Maheswaran, and J. R. Leninger, Abstr. N. Am. Symp. Bovine Respir. Dis., 1983). In recent retrospective studies, the capacity of cattle sera to neutralize cytotoxin was correlated with development of fibrinous pneumonia and survival from naturally occurring disease $(6,20)$. In studies in our laboratory, CN titers determined by testing serial dilutions of cattle sera correlated directly with resistance of animals to a transthoracic, intrapulmonic challenge with live organisms (9). High antibody titers to somatic antigens in sera from the same animals did not correlate with resistance. Therefore, it appears that determination of the serum $\mathrm{CN}$ capacity of a calf may be an important indication of its relative resistance to pneumonic pasteurellosis.

Serum cytotoxin neutralization studies are performed with assays that quantitate killing of cells exposed to cytotoxin which has been preincubated with serial dilutions of serum. The trypan blue exclusion method used by Gentry et al. (9) is labor intensive and requires staggered incubation of samples, because each one must be counted individually. This limits the number of sera which can be processed in 1 day.

\footnotetext{
* Corresponding author.

$\dagger$ Journal article no. 4803 from the Agricultural Experiment Station, Oklahoma State University, Stillwater, OK 74078.
}

Cho et al. (6) and Shewen and Wilkie (20) used ${ }^{51} \mathrm{Cr}$-release methods to determine $\mathrm{CN}$ titers. The ${ }^{51} \mathrm{Cr}$-release assay system allows concurrent incubation and harvesting of many samples. However, triplicate or quadruplicate sampling techniques are recommended, and laboratories using the method must have a gamma counter and be licensed to use radioisotopes.

Recently, an automated colorimetric assay performed in flat-bottomed microtiter plates was reported (C. N. Greer and P. E. Shewen, Annu. Meet. Conf. Res. Workers Anim. Dis., abstr. no. 154, 1984). This assay is based on the assumption that only viable cells are stained by the dye neutral red. It is used to estimate cell survival after exposure to cytotoxin by spectrophotometric measurement of the quantity of neutral red released by solubilization of treated, stained, and washed cell monolayers. This assay is rapid and does not use radioisotopes but does require a spectrophotometer equipped to read microtiter plate wells. Preincubation of cytotoxin and serum also had to be performed in separate tubes.

Direct assays of antibody to cytotoxin are not available, because crude cytotoxin contains numerous $P$. haemolytica antigens. Attempts to purify the cytotoxin have resulted in various estimates of its molecular weight and often have resulted in loss of toxicity $(2,10)$. Until a more purified product becomes available, it is particularly important to have a practical assay for determination of $\mathrm{CN}$ titers. The visual $\mathrm{CN}$ assay presented herein is rapid, simple, and inexpensive. It requires no specialized equipment for viability measurement and allows six sera to be diluted and tested within a single 96-well microtiter plate.

\section{MATERIALS AND METHODS}

Cytotoxin preparation. The cytotoxins used were prepared by the method of Shewen and Wilkie (18). Briefly, $P$. haemolytica biotype A serotype 1 organisms grown to logarithmic phase in brain heart infusion broth were incubated for $1 \mathrm{~h}$ at $37^{\circ} \mathrm{C}$ in RPMI 1640 medium supplemented with $7 \%$ fetal bovine serum. The culture was then centrifuged $(13,500 \times g$ for $15 \mathrm{~min})$, and the supernatant was filter sterilized and lyophilized. Protein concentrations determined by the dye-binding assay of Bradford (5) with commercially prepared reagents (Bio-Rad Laboratories, Richmond, Calif.) 
ranged from 0.36 to $0.48 \mathrm{mg}$ of protein per $\mathrm{ml}$ for different cytotoxin lots.

Extinction endpoints determined as described below were used to standardize cytotoxin preparations. Only those lots having an extinction endpoint of 1/64 were used in the assay.

Antisera used. Bovine sera were collected from calves which had been used in seven different vaccination trials conducted in our laboratory $(7,8,15)$. At a 7 -day interval, the calves had received two vaccinations of (i) phosphatebuffered saline (PBS), (ii) live $P$. haemolytica organisms, or (iii) a $P$. haemolytica bacterin. Blood was collected 14 days after the second immunization. Control serum without antibodies to $\boldsymbol{P}$. haemolytica was obtained from a newborn calf before suckling and was designated colostrum-deprived calf serum (CDCS). All sera were heat inactivated $\left(56^{\circ} \mathrm{C}, 30\right.$ min).

Leukocyte preparations. Heparinized blood was collected from healthy donor calves. Mixed peripheral blood leukocytes (MPBL) were separated from erythrocytes by hypotonic lysis with distilled water followed by the addition of double-strength PBS (14). The MPBL were collected by centrifugation $(700 \times g$ for $20 \mathrm{~min})$, the pellets from several tubes were combined, and the lysis procedure was repeated. The final cell pellets were pooled, washed twice with PBS, and suspended in RPMI 1640 to a final concentration of $10^{7}$ cells per $\mathrm{ml}$.

When peripheral blood polymorphonuclear leukocytes (PMNL) were used, they were prepared by differential centrifugation on Ficoll-Paque (Pharmacia, Inc., Piscataway, N.J.) followed by hypotonic lysis of the erythrocyte-PMNL pellets and processing of the PMNL as described above to yield a final cell suspension in RPMI 1640 of $10^{7}$ cells per ml.

For several experiments, cells were labeled with ${ }^{51} \mathrm{Cr}$ by suspension of $10^{7}$ cells per $\mathrm{ml}$ in RPMI 1640 containing $50 \mu \mathrm{Ci}$ of $\mathrm{Na}_{2}\left[{ }^{51} \mathrm{Cr}\right] \mathrm{O}_{4}$ per $\mathrm{ml}$ in normal saline (ICN Pharmaceuticals Inc., Irvine, Calif.). The cells were incubated for $1 \mathrm{~h}$ at $37^{\circ} \mathrm{C}$ in a shaker bath, washed 3 times in PBS, and suspended in RPMI 1640 to a concentration of $10^{7}$ cells per ml.

Trypan blue exclusion $\mathrm{CN}$ assay. All $\mathrm{CN}$ assays performed by trypan blue exclusion used PMNL as target cells. Sera to be tested were diluted in PBS by serial twofold dilutions, and all serum dilutions were tested for their $\mathrm{CN}$ ability by a previously described method (9). Briefly, $200 \mu$ l of lyophilized cytotoxin reconstituted at $1.5 \times$ concentration was added to $100 \mu$ l of a given serum dilution. The mixture was incubated at $37^{\circ} \mathrm{C}$ for 10 min before being added to a PMNL suspension in a siliconized glass tube. Cells were incubated with the serum-cytotoxin mixture for $1 \mathrm{~h}$ at $37^{\circ} \mathrm{C}$ and then examined in a hemacytometer for ability to exclude trypan blue dye. A protection index, which accounted for daily variations in controls, was calculated for each serum dilution, and the $\mathrm{CN}$ titer for a serum was defined as the reciprocal of the highest dilution affording a protection index of at least 0.80 .

Visual CN assay. The assay was performed in $350-\mu l$ well capacity, round bottomed, 96-well tissue culture plates (Cell Wells; Corning Glass Works, Corning, N.Y.). Twofold serial dilutions of sera to be tested were made directly in the plates as follows. PBS $(65 \mu \mathrm{l})$ was added to each well of the plate except the first four wells of row $\mathrm{H}$, which were reserved for controls. Serum samples $(65 \mu \mathrm{l})$ were added to duplicate wells of row A. A digital 12-channel micropipette (Titertek; Flow Laboratories, Inc., McLean, Va.) was then used to mix the well contents in row A and transfer $65 \mu$ l to the wells in row $B$, then row $C$, etc. In this way, serial dilutions were simultaneously performed on six sera in duplicate. Sixty-five microliters was discarded from the final well in each dilution series. To the four control wells (wells 1 to 4 of row $\mathrm{H}$ ), 65 $\mu l$ of CDCS was added.

Cytotoxin $(135 \mu \mathrm{l})$ reconstituted at $1.5 \times$ concentration was added to all wells except wells 1 and 2 of row $H$, to which was added $135 \mu$ l of RPMI 1640. The plate was incubated for $10 \mathrm{~min}$ at room temperature, and then $100 \mu \mathrm{l}$ of a suspension of target cells $\left(10^{7}\right.$ cells per $\mathrm{ml}$ in RPMI 1640) was added to each well. The plate was incubated for $1 \mathrm{~h}$ at $37^{\circ} \mathrm{C}$ in $5 \% \mathrm{CO}_{2}$ and then centrifuged for $10 \mathrm{~min}$ at $200 \times \mathrm{g}$ The supernatant was removed by inverting and sharply flicking the plate. The cell pellets were fixed for $30 \mathrm{~min}$ with $100 \mu \mathrm{l}$ of $10 \%$ Formalin per well, stained for 5 min with 150 $\mu l$ of $1 \%$ aqueous crystal violet per well, rinsed under running tap water, and patted dry.

Interpretation of results was made by visual examination for the presence of a purple cell layer in the bottom of each well. An intact cell layer, indicating $\mathrm{CN}$, was scored as a positive result, whereas complete absence of a cell layer or presence of only a cell layer remnant, indicating toxicity, was scored as a negative result. Wells 1 and 2 of row $H$ served as a positive control, and wells 3 and 4 of row $H$ served as a negative control. The $\mathrm{CN}$ titer of the serum was defined as the reciprocal of the serum dilution contained in the last positively scored wells. In rare cases in which duplicate samples were scored differently, the higher of the two titers was recorded.

${ }^{51} \mathrm{Cr}$-release $\mathrm{CN}$ assay. This assay was performed exactly like the visual assay with the following modifications. (i) ${ }^{51} \mathrm{Cr}$-labeled target cells were used; (ii) after centrifugation of the plate, $200 \mu$ l of supernatant was transferred from each well to a plastic tube for counting in an automated gamma counter (Searle Analytical Co.); and (iii) a third set of control wells was added, which contained $65 \mu$ l of PBS and $135 \mu$ l of cytotoxin. A visual assay was sometimes performed on the same plate by addition of $100 \mu \mathrm{l}$ of $10 \%$ Formalin to the remaining supernatant in each well. Fixation of the cell pellets was then allowed to continue overnight before staining of the plate as described previously.

Calculation of percent killing and the protection index was performed according to the following formulas: percent killing $=([$ counts per minute of test sample - counts per minute of PBS negative control]/[counts per minute of positive control - counts per minute of PBS negative control]) $\times 100$; and $\mathrm{PI}=$ (percent killing with CDCS - percent killing with test serum)/percent killing with CDCS.

Determination of cytotoxin extinction endpoint. Serial twofold dilutions in RPMI 1640 were prepared of lyophilized cytotoxin samples which had been reconstituted at $1.5 \times$ with distilled water. Diluted cytotoxin samples $(135 \mu \mathrm{l})$ were added to duplicate wells of a 96-well microtiter plate. To simulate the condition of a $\mathrm{CN}$ assay, we added $65 \mu \mathrm{l}$ of a $10 \%$ solution of CDCS in PBS to each well. The plate was incubated for $10 \mathrm{~min}$ at room temperature, $100 \mu \mathrm{l}$ of a target cell suspension was added to each well, and the plate was then processed exactly as it would have been for a ${ }^{51} \mathrm{Cr}$ release or a visual $\mathrm{CN}$ assay or both. The cytotoxin extinction endpoint was defined as the highest cytotoxin dilution causing ${ }^{51} \mathrm{Cr}$ release of at least $60 \%$ of maximum or the highest dilution contained in the last positively scored wells of a visual assay.

Comparison of visual $\mathrm{CN}$ titers with resistance. Visual $\mathrm{CN}$ titers performed on $\mathbf{4 0}$ sera from cattle used in vaccination experiments were compared by linear regression analysis (1) with lesion scores calculated for the calves as previously 
described (16). Briefly, lesion scores ranging from 0 to 20 were ascribed to each animal according to specific morphological parameters of the lung lesions induced by a transthoracic, intrapulmonic challenge with live $P$. haemolytica. The higher the lesion score, the more susceptible the calf was to the challenge.

Testing of $\mathrm{CN}$ capacity of serum fractions. We fractionated serum from a steer hyperimmunized with live $P$. haemolyti$c a$ on an Ultrogel-ACA 34 gel filtration column (LKB Instruments, Inc., Rockville, Md.) to obtain purified immunoglobulin. Duplicate $65-\mu l$ samples of serum fractions were tested for $\mathrm{CN}$ capacity by a standard ${ }^{51} \mathrm{Cr}$-release assay followed by visual staining of the remaining cell pellets. Percent specific release of ${ }^{51} \mathrm{Cr}$ from the cells was calculated by the following formula: percent specific release $=([$ counts per minute of test sample - counts per minute of negative control]/[counts per minute of positive control - counts per minute of negative control]) $\times 100$, where negative control $=$ wells containing $65 \mu \mathrm{l}$ of CDCS $+135 \mu \mathrm{l}$ of cytotoxin and positive control $=$ wells containing $65 \mathrm{ml}$ of CDCS $+135 \mu \mathrm{l}$ of RPMI 1640.

Statistical analysis. Comparison of mean lesion scores and $\mathrm{CN}$ titers for groups of animals divided according to vaccination treatments were made with a multiple $t$ test by the least-square-difference procedure (17). Reproducibility of the visual $\mathrm{CN}$ assay performed on the same sera on different days was evaluated by analysis of variance of the natural logarithms of mean daily titers (17).

\section{RESULTS}

Comparison of visual, trypan blue, and ${ }^{51} \mathrm{Cr}$-release assays. To date, visual $\mathrm{CN}$ titers have been performed in our laboratory on 86 sera from calves which have been used in vaccination trials. The titers determined on these sera have ranged from $<2$ to $>512$, with the vast majority being in the range of 2 to 128 (Fig. 1). $\mathrm{CN}$ titers for 11 sera were compared by visual, trypan blue exclusion, and ${ }^{51} \mathrm{Cr}$-release assays (Table 1). Although titers were determined by the three methods on different target cell populations on sepa-

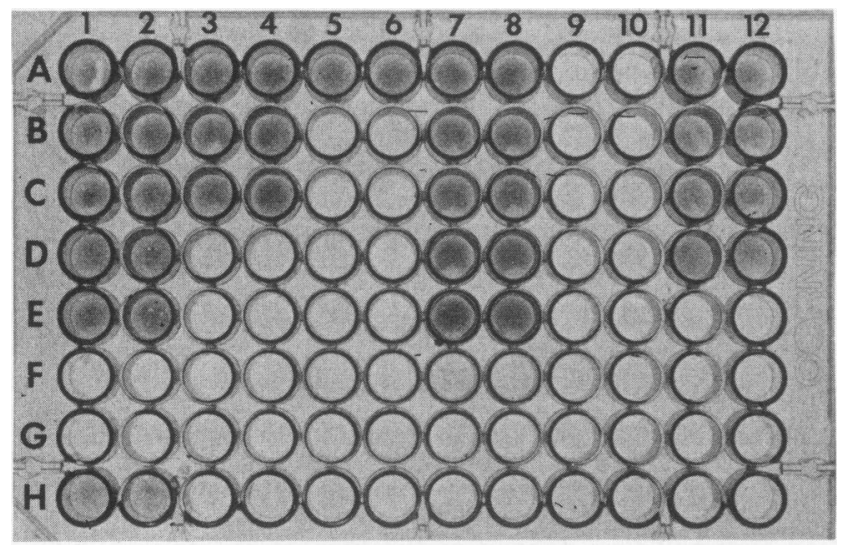

FIG. 1. Stained plate used in a $\mathrm{CN}$ assay. Six sera were assayed in duplicate in dilutions ranging from $1 / 2$ in row $A$ to $1 / 256$ in row $\mathrm{H}$. Dark wells contained intact cell layers and were scored positively, whereas light wells indicated disrupted cell layers and were scored negatively. The $\mathrm{CN}$ titers thus determined for the six sera represented were $32,8,2,32,<2$, and 16 , respectively. Wells $\mathrm{H} 1$ and $\mathrm{H} 2$ served as positive controls, and wells $\mathrm{H} 3$ and $\mathrm{H} 4$ served as negative controls.
TABLE 1. Comparison of three $\mathrm{CN}$ assays

\begin{tabular}{cccc}
\hline & \multicolumn{3}{c}{ CN titer determined by: } \\
\cline { 2 - 4 } Antiserum no. & $\begin{array}{c}\text { Trypan blue }_{\text {exclusion }^{a}} \\
{ }^{51} \text { Cr release }\end{array}$ & $\begin{array}{c}\text { Visual } \\
\text { assay }^{b}\end{array}$ \\
\hline 1 & 32 & 32 & 64 \\
2 & 16 & 16 & 32 \\
3 & 32 & 64 & 64 \\
4 & 128 & 128 & 64 \\
5 & 64 & 64 & 128 \\
6 & 8 & 4 & 8 \\
7 & 16 & 16 & 32 \\
8 & 64 & 32 & 64 \\
9 & 16 & 16 & 32 \\
10 & 32 & 16 & 32 \\
11 & 32 & 16 & 32 \\
\hline
\end{tabular}

${ }^{a} \mathrm{CN}$ titer is expressed as the reciprocal of the highest serum dilution affording a protection index $>0.80$.

${ }^{b} \mathrm{CN}$ titer is expressed as the reciprocal of the highest serum dilution contained in the last positively scored wells.

rate days, they never varied by more than 1 dilution for any given serum. The trypan blue result was 1 dilution lower than the other two for 1 of the 11 sera. The ${ }^{51} \mathrm{Cr}$-release result was 1 dilution lower than the other two for 4 of the sera. The visual assay result was 1 dilution lower for one serum and 1 dilution higher for five sera than those of the other two methods. Titers determined for 17 additional sera by visual and ${ }^{51} \mathrm{Cr}$-release assays performed on the same plates correlated perfectly (data not shown).

Reproducibility of visual assay. To examine the reproducibility of the assay system, we determined $\mathrm{CN}$ titers by the visual assay five different times for the same 12 sera (Table 2). The trials were performed on four separate days with target cells from three different animals. For 5 of the 12 sera, all five trials resulted in the same titer. For four sera, four of the five trials were in agreement. For the three additional sera, three of the five trials agreed, with the remaining titers in each case being 1 dilution higher or lower. The results did not differ significantly from day to day $(P=0.25)$.

Variation of target cell population. Titers of eight sera were identical when determined simultaneously with MPBL or

TABLE 2. Reproducibility of the visual CN assay on different days and with different target cell preparations ${ }^{a}$

\begin{tabular}{crrrrrr}
\hline $\begin{array}{c}\text { Antiserum } \\
\text { no. }\end{array}$ & \multicolumn{4}{c}{$\mathrm{CN}$ titer $^{b}$ determined for trial no.: } & \multicolumn{1}{c}{$\begin{array}{c}\text { No. of trials } \\
\text { in agreement }\end{array}$} \\
\cline { 2 - 5 } 5 & \multicolumn{1}{c}{2} & \multicolumn{1}{c}{3} & 4 & 5 & \\
\hline 576 & 128 & 128 & 128 & 128 & 128 & 5 \\
581 & 16 & 16 & 16 & 16 & 8 & 4 \\
583 & 32 & 32 & 32 & 32 & 32 & 5 \\
584 & 8 & 8 & 8 & 8 & 8 & 5 \\
585 & 4 & 4 & 8 & 8 & 4 & 3 \\
587 & 32 & 32 & 32 & 16 & 16 & 3 \\
588 & 2 & 2 & 2 & 4 & 2 & 4 \\
601 & 64 & 32 & 64 & 64 & 32 & 3 \\
604 & 4 & 4 & 4 & 4 & 4 & 5 \\
627 & 16 & 32 & 16 & 16 & 16 & 4 \\
630 & 2 & 2 & 2 & 2 & 2 & 5 \\
632 & 128 & 128 & 128 & 64 & 128 & 4 \\
\hline
\end{tabular}

a Assays were performed on four separate days with MPBL from three different target cell donors. The mean titers in trials 1 through 5 were 36.3, $35.0,36.7,30.2$, and 31.7 , respectively, and they did not differ significantly $(P$ $=0.25$ ).

${ }^{b}$ Titer is expressed as the reciprocal of the highest serum dilution contained in the last positively scored wells. 
PMNL from the same animal as the target cells. For such paired assays, however, the stain intensity was greater and results were more easily interpreted when PMNL were used. There was also an obvious difference in intensity of staining when cells from different animals were used. These variations could not be related to differences in initial viability or differential cell count of the target cell preparations (data not shown) and were found to be consistent for given animals on a day-to-day basis. Attempts to use target cells at concentrations of $<10^{7}$ cells per $\mathrm{ml}$ resulted in inadequate staining with MPBL from certain animals.

Variations in cytotoxin preparations. Use of cytotoxin preparations which had been reconstituted at concentrations $<1.5 \times$ (allowing a final concentration of $<1 \times$ in the test wells) resulted in increased titers for certain sera. To determine the effect of using different lots of lyophilized cytotoxin on $\mathrm{CN}$ titers, we performed assays for three sera with cytotoxin samples prepared in our laboratory on six different days in 10 separate lots (Table 3 ). With 9 of the 10 cytotoxin preparations, the titers obtained for each of the sera agreed within 1 dilution. Cytotoxin B was apparently less toxic, allowing each of the sera to neutralize at two- to threefold higher dilutions. The differences in titers of the three sera when tested with various cytotoxin lots were also reflected in a comparison of their extinction endpoints and protein concentrations (Table 3). Comparable extinction endpoints were obtained by the ${ }^{51} \mathrm{Cr}$-release and visual assay methods for five lots of cytotoxin tested by both procedures.

Applications of the visual $\mathrm{CN}$ assay. $\mathrm{CN}$ titers were determined by the visual assay for sera from 40 calves from three experimental groups having significantly different $(P=$ 0.0001 ) degrees of resistance to a live $P$. haemolytica challenge as measured by lesion score (Table 4). Linear regression analysis of lesion score versus the natural logarithm of the $\mathrm{CN}$ titer for all $\mathbf{4 0}$ animals had a correlation coefficient of $-0.5887(P<0.001)$. At the 0.05 confidence level, the group of animals receiving live vaccine had significantly higher $\mathrm{CN}$ titers than did the PBS control group or the group receiving bacterins. The $\mathrm{CN}$ titers of bacterin-treated animals did not differ significantly from those of the PBS-treated control group.

The visual $\mathrm{CN}$ and ${ }^{51} \mathrm{Cr}$-release assays were used to screen

TABLE 3. Reproducibility of the visual $\mathrm{CN}$ assay with different preparations of cytotoxin

\begin{tabular}{cccccc}
\hline $\begin{array}{c}\text { Cytotoxin } \\
\text { prepn }^{a}\end{array}$ & \multicolumn{3}{c}{$\mathrm{CN}$ titer $^{b}$ of serum no.: } & $\begin{array}{c}\text { Extinction } \\
\text { endpoint }^{c}\end{array}$ & $\begin{array}{c}\text { Protein concn } \\
(\mathrm{mg} / \mathrm{ml})^{d}\end{array}$ \\
\hline A & 1 & 2 & 3 & & \\
B & 2 & 16 & 32 & $1 / 64$ & 0.46 \\
C & 8 & 64 & 128 & $1 / 16$ & 0.36 \\
D & 2 & 16 & 32 & $1 / 64$ & 0.42 \\
E & 4 & 32 & 64 & $1 / 32$ & 0.37 \\
F & 2 & 16 & 32 & $1 / 128$ & NT $^{e}$ \\
G & 4 & 32 & 64 & $1 / 32$ & 0.43 \\
H & 4 & 32 & 64 & $1 / 32$ & NT \\
I & 4 & 16 & 64 & $1 / 32$ & 0.42 \\
J & 4 & 16 & 64 & $1 / 32$ & NT \\
\hline
\end{tabular}

${ }^{a}$ Cytotoxin preparations prepared by the same method on different days.

${ }^{b}$ Titer is expressed as the reciprocal of the highest serum dilution contained in the last positively scored wells.

${ }^{c}$ Extinction endpoint as determined by ${ }^{51} \mathrm{Cr}$-release or visual assay or both. Endpoints are expressed as the highest dilution of cytotoxin causing at least $60 \%$ of maximum ${ }^{51} \mathrm{Cr}$ release or the highest dilution contained in the last positively scored wells of a visual assay.

${ }^{d}$ Determined by the method of Bradford (5).

e NT, Not tested.
TABLE 4. Mean CN titers, as measured by the visual assay, for calves from vaccination trials

\begin{tabular}{lccr}
\hline $\begin{array}{c}\text { Treatment } \\
\text { group }\end{array}$ & $\begin{array}{c}\text { No. of } \\
\text { animals }\end{array}$ & \multicolumn{1}{c}{$\begin{array}{c}\text { Mean visual } \\
\text { CN } \text { titer }^{b}\end{array}$} & \multicolumn{1}{c}{$\begin{array}{c}\text { Lesion } \\
\text { score }^{b}\end{array}$} \\
\hline PBS & 14 & $4.8 \pm 2.1$ & $15.7 \pm 5.1$ \\
Bacterin & 13 & $7.9 \pm 2.3$ & $13.4 \pm 7.6$ \\
Live vaccine & 13 & $70.2 \pm 1.7$ & $4.1 \pm 1.9$
\end{tabular}

${ }^{a}$ Animals received two injections at a 1-week interval of PBS, a commercial $P$. multocida and $P$. haemolytica bacterin containing an $\mathrm{Al}(\mathrm{OH})_{3}$ adjuvant, or a live culture of $P$. haemolytica containing $5 \times 10^{9} \mathrm{CFU}$.

${ }^{b}$ Values represent means \pm standard deviations.

serum fractions for neutralizing capacity (Fig. 2). All fractions affording a percent specific release of greater than $40 \%$ were negative by visual assay, whereas all fractions allowing a percent specific ${ }^{51} \mathrm{Cr}$ release of less than $40 \%$ were visual assay positive. In similar experiments, a positive visual assay has correlated with percent specific releases ranging from 20 to $35 \%$ (data not shown).

\section{DISCUSSION}

The visual $\mathrm{CN}$ assay described herein tests the capacity of bovine serum to neutralize $P$. haemolytica cytotoxin. Results with this assay were comparable to those obtained by both the trypan blue exclusion and ${ }^{51} \mathrm{Cr}$-release assays. The advantages of the visual $\mathrm{CN}$ assay over trypan blue exclusion are that it is less labor intensive and more sera can be tested at one time. The visual assay also has several advantages over ${ }^{51} \mathrm{Cr}$ release, including decreased time involved and the use of duplicate rather than triplicate samples. Most important, the visual assay does not require the use of radioisotopes, which includes such considerations as expense, safety, and disposal of radioactive wastes, as well as the requirement for a gamma counter. Additional advantages of the visual $\mathrm{CN}$ assay are that it requires no specialized equipment, making it adaptable to most laboratories, and permanent records of results may be made by photocopying stained plates.

The visual $\mathrm{CN}$ assay has been shown to be reproducible when care is taken to standardize the cytotoxin preparation used. This may be accomplished by performing an endpoint titration of each lot of cytotoxin used in the assay. Although comparable extinction endpoints were obtained with the ${ }^{51} \mathrm{Cr}$-release and visual assay procedures, use of the ${ }^{51} \mathrm{Cr}$ release assay is recommended for determining cytotoxin extinction endpoints. Interpretation of the visual assay was

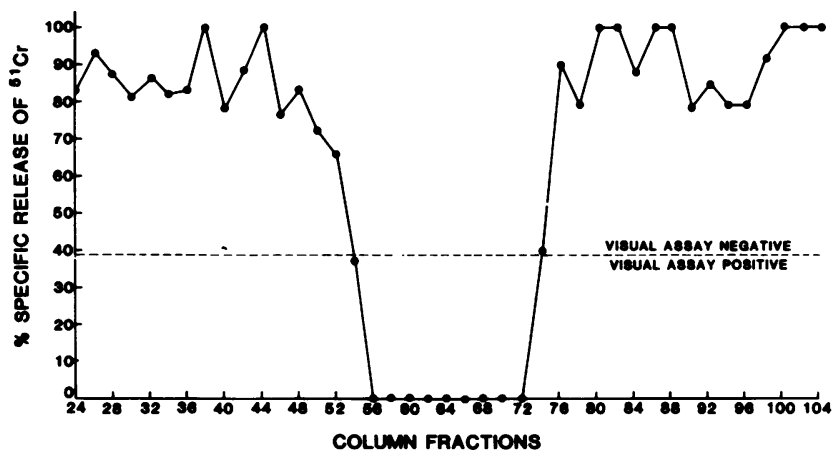

FIG. 2. Comparison of the visual and ${ }^{51} \mathrm{Cr}$-release assays for detection of $\mathrm{CN}$ capacity of serum fractions. A positive visual assay correlated with a percent specific ${ }^{51} \mathrm{Cr}$ release of $40 \%$. Fractions 54 to 72 were designated for pooling on the basis of each assay. 
sometimes impossible. In those cases, stainable cell layers were not formed, even at cytotoxin dilutions which did not cause release of ${ }^{51} \mathrm{Cr}$ from the cells. This phenomenon may be due to cytoplasmic membrane damage by nonlethal cytotoxin concentrations, preventing adherence, and thus cell layer formation, by viable target cells.

To ensure more consistent results from day to day in our laboratory, we prepare and lyophilize 2-liter volumes of cytotoxin at one time, and then store them at $4^{\circ} \mathrm{C}$ for subsequent use. Only those preparations having an extinction endpoint of $1 / 64$ are used. Lots with other endpoints may be used after appropriate dilution or concentration.

The test is applicable for assaying neutralization of cytotoxin with either PMNL or MPBL. The increased intensity of staining with PMNL is most likely due to the higher percentage of cells that can attach to plastic and thus be less easily dislodged from the plate during the fixation and staining procedures. The disadvantages of using PMNL rather than MPBL are the cost of the Ficoll-Paque required and additional time needed for their isolation. Although the results obtained with target cells from different animals were comparable, we found that cells from certain donor calves consistently provided more intense staining than those from other calves. We were unable to explain these differences on the basis of initial viability or differential cell counts, but we did observe that cells derived from readily excitable animals were less likely to stain intensely. This phenomenon may be due to induction of increased levels of corticosteroids in excitable animals during the blood collection procedure. Administration of glucocorticoids in man has been shown to decrease the adherence properties of neutrophils (16).

The CN titer of the serum of an animal may be used as an indicator of its relative resistance to a live $P$. haemolytica challenge. A comparison by linear regression analysis of sera from 40 animals in three experimental groups with their resistance to experimental challenge as indicated by their postchallenge lesion scores showed a highly significant negative correlation. Thus, the greater the $\mathrm{CN}$ titer of the serum of an animal, the more resistant it was likely to be to a challenge with live organisms. $\mathrm{CN}$ titers also have been shown to be more reliable than titers of serum to somatic antigens as an indicator of prior exposure to the organism (10). We are currently using the visual $\mathrm{CN}$ assay as one of our criteria to determine the previous exposure of an animal to $P$. haemolytica and to measure the efficacy of experimental vaccines.

The visual $\mathrm{CN}$ assay also may be used as a screening tool when purifying immunoglobulin from serum collected from an immunized animal. In several trials, the visual assay identified all serum fractions affording at least a 60 to $80 \%$ reduction in cytotoxin activity, making it essentially as sensitive as the ${ }^{51} \mathrm{Cr}$-release assay for identifying fractions with $\mathrm{CN}$ capabilities. In conclusion, the visual $\mathrm{CN}$ assay is a simple, rapid, inexpensive, and reliable test for determination of $\boldsymbol{P}$. haemolytica $\mathrm{CN}$ titers of cattle sera.

\section{ACKNOWLEDGMENTS}

This work was supported in part by special grant no. 83-CRSR-2-2195 from the U.S. Department of Agriculture.

We thank René Simons, Chad Faulkner, and Derek Mosier for assistance in preparation of cytotoxins and blood collection, as well as Johnny Johnson for typing the manuscript.

\section{LITERATURE CITED}

1. Bailey, N. T. J. 1981. Statistical methods in biology, 2nd ed. p. 133-145. John Wiley \& Sons, Inc., New York.

2. Baluyut, C. S., R. R. Simonson, W. J. Bemrick, and S. K. Maheswaran. 1981. Interaction of Pasteurella haemolytica with bovine neutrophils: identification and partial characterization of a cytotoxin. Am. J. Vet. Res. 42:1920-1926.

3. Bensen, M. L., R. G. Thomson, and V. E. O. Valli. 1978. The bovine alveolar macrophage. II. In vitro studies with Pasteurella haemolytica. Can. J. Comp. Med. 42:368-369.

4. Berggren, K. A., C. S. Baluyut, R. R. Simonson, W. J. Bemrick, and S. K. Maheswaran. 1981. Cytotoxic effects of Pasteurella haemolytica on bovine neutrophils. Am. J. Vet. Res. 42:1383-1388.

5. Bradford, M. M. 1976. A rapid and sensitive method for the quantitation of microgram quantities of protein utilizing the principle of protein-dye binding. Anal. Biochem. 72:248-254.

6. Cho, H. J., J. G. Bohac, W. D. G. Yates, and H. B. Ohmann. 1984. Anticytotoxin activity of bovine sera and body fluids against Pasteurella haemolytica A1 cytotoxin. Can. J. Comp. Med. 48:151-155.

7. Confer, A. W., R. J. Panciera, and R. W. Fulton. 1984. Effect of prior natural exposure to Pasteurella haemolytica on experimental bovine pneumonic pasteurellosis. Am. J. Vet. Res. 45:2622-2624.

8. Confer, A. W., R. J. Panciera, R. W. Fulton, M. J. Gentry, and J. A. Rummage. 1985. Effect of vaccination with live or killed Pasteurella haemolytica on resistance to experimental bovine pneumonic pasteurellosis. Am. J. Vet. Res. 46:342-347.

9. Gentry, M. J., A. W. Confer, and R. J. Panciera. 1985. Serum neutralization of cytotoxin from Pasteurella haemolytica serotype-1 and resistance to experimental bovine pneumonic pasteurellosis. Vet. Immunol. Immunopathol. 9:239-250.

10. Himmel, M. E., M. D. Yates, L. H. Lauerman, and P. G. Squire. 1982. Purification and partial characterization of a macrophage cytototoxin from Pasteurella haemolytica. Am. J. Vet. Res. 43:764-767.

11. Kaehler, K. L., R. J. F. Markham, C. C. Muscoplat, and D. W. Johnson. 1980. Evidence of cytocidal effects of Pasteurella haemolytica on bovine peripheral blood mononuclear leukocytes. Am. J. Vet. Res. 41:1690-1693.

12. Kaehler, K. L., R. J. F. Markham, C. C. Muscoplat, and D. W. Johnson. 1980. Evidence of species specificity in the cytocidal effects of Pasteurella haemolytica. Infect. Immun. 30:615-616.

13. Markham, R. J. F., and B. N. Wilkie. 1980. Interaction between Pasteurella haemolytica and bovine alveolar macrophages: cytotoxic effects on macrophages and impaired phagocytosis. Am. J. Vet. Res. 41:18-22.

14. Mishell, B. B., and S. M. Shiigi. 1980. Selected methods in cellular immunology, p. 16-17, 22. W. H. Freeman \& Co., San Francisco.

15. Panciera, R. J., R. E. Corstvet, A. W. Confer, and C. N. Gresham. 1984. Bovine pneumonic pasteurellosis: effect of vaccination with live Pasteurella species. Am. J. Vet. Res. 45:2538-2542.

16. Roth, J. A., and M. L. Kaeberle. 1982. Effects of glucocorticoids on the bovine immune system. J. Am. Vet. Med. Assoc. 180:894-901.

17. SAS Institute, Inc. 1982. SAS user's guide: statistics, 1982 ed., p. 113-229. SAS Institute, Inc., Cary, N.C.

18. Shewen, P. E., and B. N. Wilkie. 1982. Cytotoxin of Pasteurella haemolytica acting on bovine leukocytes. Infect. Immun. 35:91-94.

19. Shewen, P. E., and B. N. Wilkie. 1983. Pasteurella haemolytica cytotoxin: production by recognized serotypes and neutralization by type-specific rabbit antisera. Am. J. Vet. Res. 44:715-719.

20. Shewen, P. E., and B. N. Wilkie. 1983. Pasteurella haemolytica cytotoxin neutralizing activity in sera from Ontario beef cattle. Can. J. Comp. Med. 47:497-498. 